\title{
URBAN GREEN AREAS TO IMPROVE THE QUALITY OF LIFE IN THE SAN JUAN DE MIRAFLORES DISTRICT
}

\author{
Karina Hinojosa Pedraza \\ Federico Villarreal National University, Lima, (Peru). \\ E-mail:khinojosa@unfv.edu.pe \\ ORCID: https://orcid.org/0000-0003-1237-9110
}

Doris Esenarro

Federico Villarreal National University, Lima, (Peru).

E-mail: desenarro@unfv.edu.pe

ORCID: https://orcid.org/0000-0002-7 186-9614

Lucy Brigite Mio Morales

Federico Villarreal National University, Lima, (Peru).

E-mail:2016019827@unfv.edu.pe

ORCID: https://orcid.org/0000-0003-4975-1334

Wilson Vasquez Gerdan

Universidad Privada del Norte, Lima, (Peru).

E-mail: wilson.cerdan@upn.edu.pe

ORCID: https://orcid.org/0000-0001-7064-028X

Recepción: 01/12/2020 Aceptación: 25/02/2021 Publicación: 07/05/2021

Gitación sugerida:

Hinojosa, K., Esenarro, D., Mio, L. B., y Vasquez, W. (2021). Urban green areas to improve the quality of life in the San Juan de Miraflores district. 3C Tecnología. Glosas de innovación aplicadas a la pyme, Edición Especial, (mayo 2021), 135-147. https://doi.org/10.17993/3ctecno.2021.specialissue7.135-147 


\section{ABSTRACT}

This research seeks to propose a design of ecological green areas in the district of San Juan de Miraflores, Panamericana Sur sector. The lack of green spaces increases environmental pollution and affects the health of the residents of the neighborhood, the proposal to incorporate green areas in public spaces aims to improve the quality of life, in the methodology used to determine the location, a topographic survey of the district identifying the existing green areas, as well as evaluating the climatology, soil science, flora and fauna of the place and the urban environment for the design in such a way that it generates microclimates. It also had the support of a virtual survey directed to the residents of the area. As a final result, the design of a proposal for ecological spaces that integrate with the urban environment without losing their identity and minimizing their relationship with nature is proposed for users' interaction and comfort using clean technologies.

\section{KEYWORDS}

Green Areas, Quality of life, Urban environment, Sustainability. 


\section{INTRODUCTION}

The Health Municipality Organization (WHO) recommends 9 to $12 \mathrm{~m} 2$ of green areas per inhabitant; this comes to make an indicator that highlights the level of quality of life in a district or city (Gómez \& Velázquez, 2018). Lima, the capital, the fifth most populous city in the ranking of Latin America and the Caribbean, has a deficit of 56 million m2 of green areas, equivalent to more than five thousand soccer fields (Ramos et al., 2020). In this regard, the District of San Juan de Miraflores, which is home to approximately 355,299 inhabitants (Amaya et al., 2020), only has around $1.69 \mathrm{~m} 2$ of green areas per inhabitant, which is insufficient, ranking among the 15 districts with the least green spaces in all of Metropolitan Lima (INEI, 2017), that is, below that recommended by the World Health Organization, this increases the need to establish various mechanisms to achieve the recommended figure. This decrease in green areas causes citizens' quality of life to be negatively affected by not having the environmental benefits provided by green places or similar public spaces and not meeting recommended international standards (SINIA, 2016).

The influence of urban green areas on the quality of life of the population is an issue that has only recently been incorporated into the political and scientific agenda. There is not yet a strong current of public opinion interested in claiming the social importance of these natural areas (Berrocal, 2020), is what is evidenced in the District of San Juan de Miraflores, there is an excellent disinterest of the authorities added to the accelerated urban expansion, the sale of illegal land, which led to the transfer of spaces destined to green areas, and in many cases, free zones have been turned into informal waste dumps (Esenarro et al., 2020). The little importance given to the planning of urban green areas means that the San Juan de Miraflores district does not have adequate green spaces, a fundamental element for improving the population's well-being, especially in large cities. Indeed, in the great cities of the world today, we speak not only of urban forests, ecological parks, networks, and green belts but also of urban green areas' naturalization (Reyes and Figueroa, 2010). Thus, it is a question of recognizing, amid urbanization or urban expansion, nature, its presence, its importance, and, therefore, the need for its conservation (Moyano \& Priego, 2009). Additionally, urban green areas can be incorporated as an element for the application of the concept of sustainability (Vega et al., 2020). 


\subsection{QUALITY OF LIFE}

The expression "quality of life" has been significantly used in everyday language and in different disciplines that deal with studying the complex economic, social, environmental, territorial, and relationship problems that characterize society. The concept of quality of life has become a pivotal perspective to understand and measure, on different scales, the conditions in which the population lives. In cities, the importance of equipment and services to improve the inhabitants' quality of life has been pointed out (Morales et al., 2018).

\section{METHODS AND MATERIALS}

\subsection{STUDY AREA}

The district of San Juan de Miraflores, in figure 1, located in the department of Lima, in Peru. It limits the north with La Molina's community, to the east with Villa María del Triunfo's district, to the south with Villa El Salvador and San Pedro de los Chorrillos, and the west with the community of Santiago de Surco. San Juan de Miraflores' district was founded on January 12, 1965, by Law 15382, and is divided into 6 zones (Municipalidad distrital de San Juan de Miraflores, 2012).

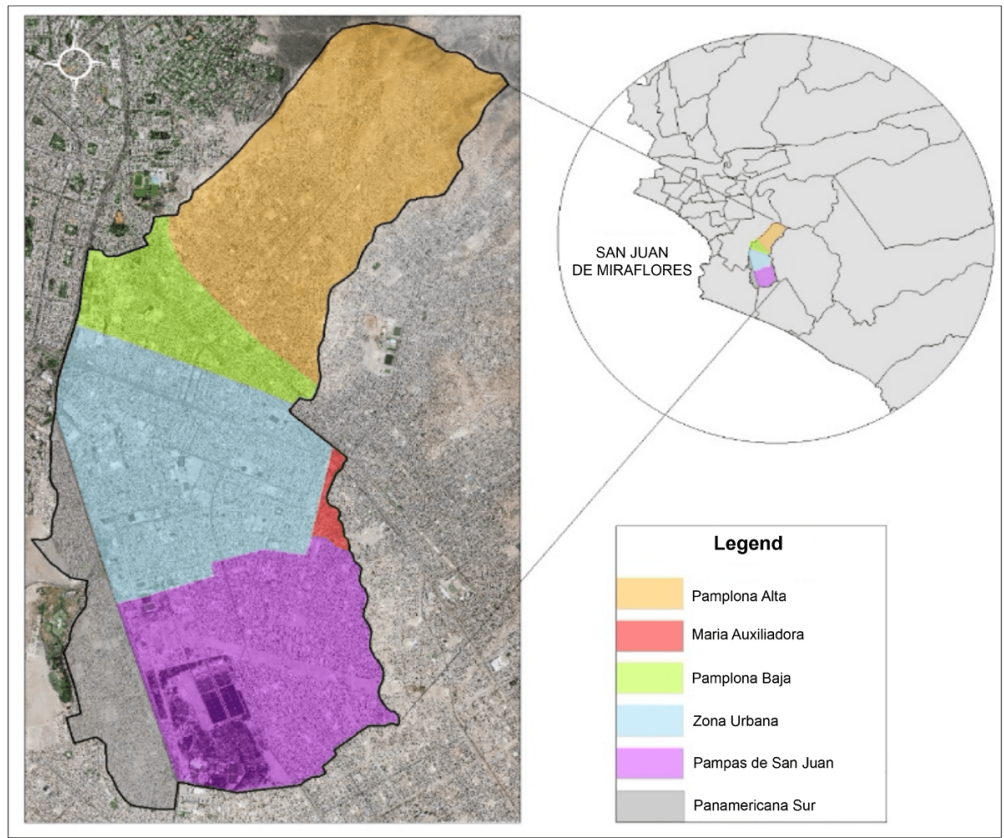

Figure 1. Map of sectors of the San Juan de Miraflores district.

Source: own elaboration. 
Figure 1 shows the delimitation of the study area and the geographical location.

\subsection{CHARACTERISTICS OF THE STUDY AREA}

The District of San Juan de Miraflores mentions the following physical and ecological characteristics (Miyasako, 2009).

Table 1. Characteristics of the San Juan de Miraflores District.

\begin{tabular}{|c|c|}
\hline Characteristic & Description \\
\hline Climate and Ecology & $\begin{array}{l}\text { The district corresponds to the tropical climatic region; However, arid and semi- } \\
\text { arid desert environments occur due to the cold Humboldt current and the Andes } \\
\text { Mountains. }\end{array}$ \\
\hline Temperature & $\begin{array}{l}\text { The annual average temperature is } 18.5^{\circ} \mathrm{C} \text {, with moderate monthly variations } \\
\text { During EI Niño phenomena, the yearly average temperature can reach } 22.84^{\circ} \mathrm{C} \\
\text { raising the monthly averages to } 18 \text { and } 27.01^{\circ} \mathrm{C} \text { depending on the month. }\end{array}$ \\
\hline $\begin{array}{c}\text { Maximum Relative } \\
\text { Humidity }\end{array}$ & $\begin{array}{l}\text { The maximum relative humidity remains between } 70 \% \text { and } 87 \% \text { and is higher in the } \\
\text { winter months. This parameter acquires a higher register in the areas closest to the } \\
\text { Rímac, Lurín rivers, and other water currents of natural or artificial origin. }\end{array}$ \\
\hline Cloudiness & $\begin{array}{l}\text { The annual average cloud cover is } 6 / 8 \text {, which can be considered high since it } \\
\text { covers } 75 \% \text { of the sky. The occurrence of cloudiness is closely linked to the therma } \\
\text { inversion that contributes to saturate the atmosphere with humidity in winter. The } \\
\text { annual total evaporation is } 1,028.6 \mathrm{~mm} \text {, which is closely related to temperature } \\
\text { since the intensity reflects the greater or lesser heat radiation of the soil, which is } \\
\text { manifested through the gasification of retained moisture }\end{array}$ \\
\hline Winds & $\begin{array}{l}\text { In the study area, the West's prevailing winds are registered, reaching an average } \\
\text { annual speed of approximately } 6.4 \mathrm{~km} / \mathrm{H} \text {, which is classified as "Weak Breeze" } \\
\text { according to the Beaufort scale. These winds are more from October to March. }\end{array}$ \\
\hline Green Areas & $\begin{array}{l}\text { The extension of green areas is } 38.4 \text { hectares. This coverage defines an average of } \\
1.1 \mathrm{~m} 2 \text { per inhabitant, far from the minimum value indicated by the OMS, which is } 8 \\
\mathrm{~m} 2 \text { per inhabitant. }\end{array}$ \\
\hline Ground & $\begin{array}{l}\text { Type II soil, granular on alluvial or colluvial gravel strata, type III high danger soil, } \\
\text { with fine dirt and thick sands, very high danger type IV soil, aeolian sands, marine } \\
\text { deposits, and swampy soils, and type V soil specific areas of Heterogeneous waste } \\
\text { deposits, with uncertain dynamic behavior. }\end{array}$ \\
\hline
\end{tabular}

Source: own elaboration.

The Table 1 shows the climatic characteristics and the vegetation cover of the study site.

\subsection{WORK AREA}

San Juan de Miraflores "Panamericana Sur" sector is located in the western part of the district. It runs along the right strip that runs parallel to the Panamericana Sur highway for an approximate extension of $6 \mathrm{~km}$. (Amauta bridge to kilometer 18 of the Panamericana). It limits the districts of Surco and Chorrillos. It has 36 human settlements, 8 Housing 
Associations, 5 Housing Cooperatives, and one Urbanization. It has 50 towns and a population of 45,000 inhabitants (9,000 families) (Segovia et al., 2020).

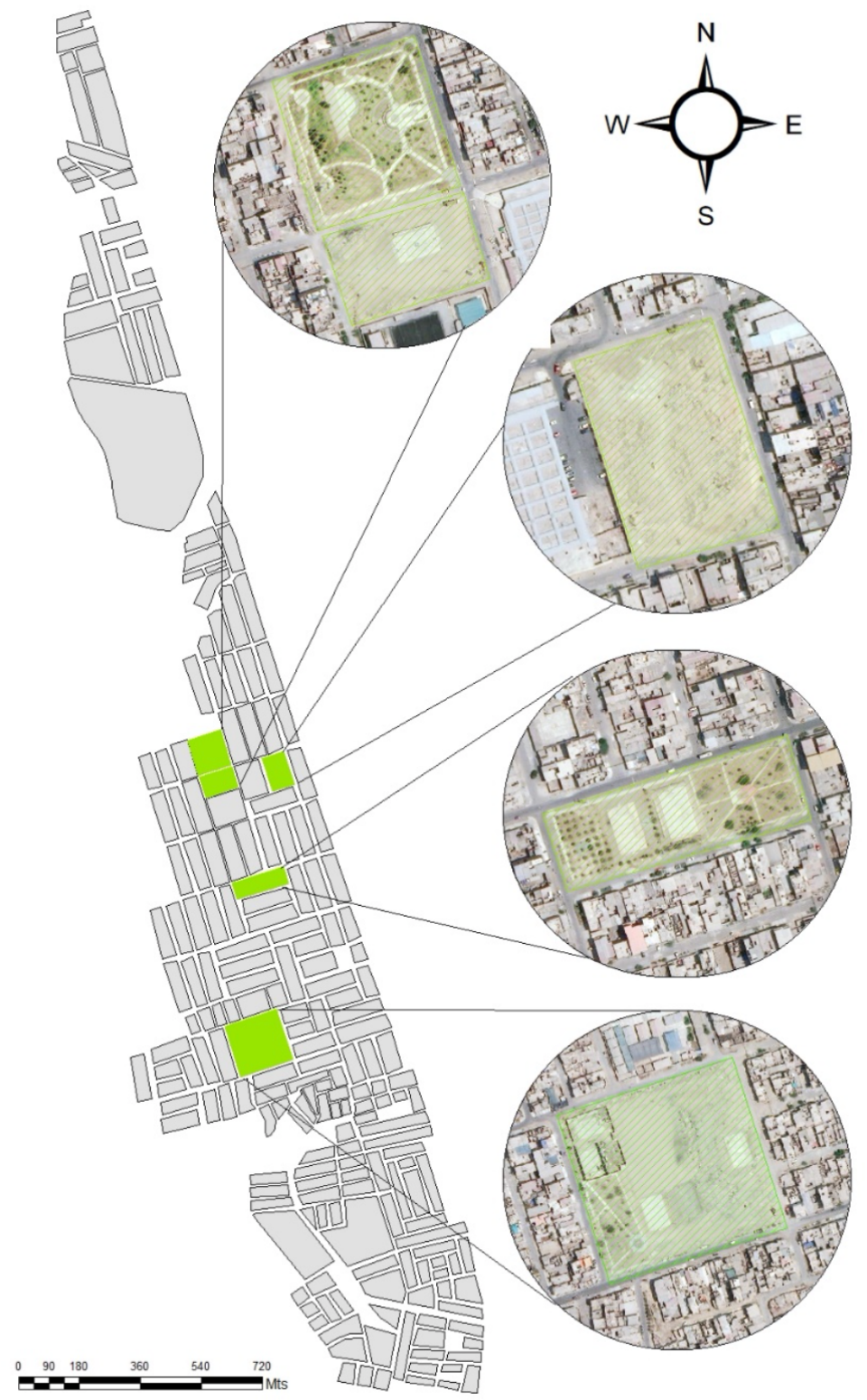

Figure 2. Map of the location of work areas.

Source: own elaboration.

Figure 2 shows the location map of the different location points of the research development, as well as the orientation of the green infrastructure. 


\subsection{PROCESS FOR THE DESIGN OF GREEN AREAS}
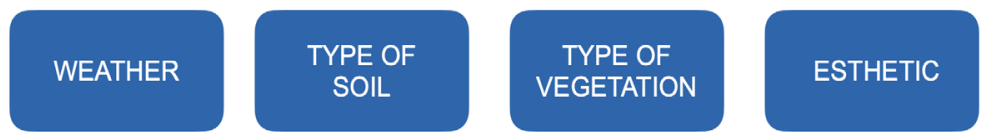

DESIGN OF

GREEN AREAS

Figure 3. Processes for the design of green areas.

Source: own elaboration.

Figure 3 shows the methodological process of the green infrastructure research.

\section{RESULTS}

An online survey was conducted in October and November for a population sample of 81 people. The results obtained show the respondents' profile, mostly female (67\%) and male $(33 \%)$. In general, a level of education corresponding to university $(42 \%)$ and complete secondary school $(26 \%)$ predominates.

There is a concordance with previous studies where the contributions of green areas to improve the quality of life include two aspects, the first contributes to the well-being of people and is considered; the promotion of sports, leisure, recreation, and aesthetic elements (Flores \& Gonzáles, 2010), similar to the result obtained in this study that shows a (75\%) think that green areas play a role of recreation and $(62 \%)$ believe that Green areas help to improve emotional well-being, however, environmental factors that affect the levels of well-being of any society that determine people's quality of life should also be considered (Falcon, 2007).

Those that have been considered in this study obtained results that show that $(66 \%)$ consider green areas vital because they help fight pollution, which indicates an environmental awareness on the part of the respondents as well as (53\%) He would like to see a large number of trees in his green areas, which is consistent with other research where trees help filter pollutant particles from the air. Research indicates that public green regions or free access (Salvador, 2003) present different types, depending on metropolitan areas. These typologies allow the differentiation of spaces according to their surface, architectural design, function (recreational, ecological, social, others), and social goals (target population). These studies are consistent with the results of the research for the design of the green area, which 
takes into consideration, and an aspect such as the inclusion of a small urban garden is added (Méndez et al., 2020).
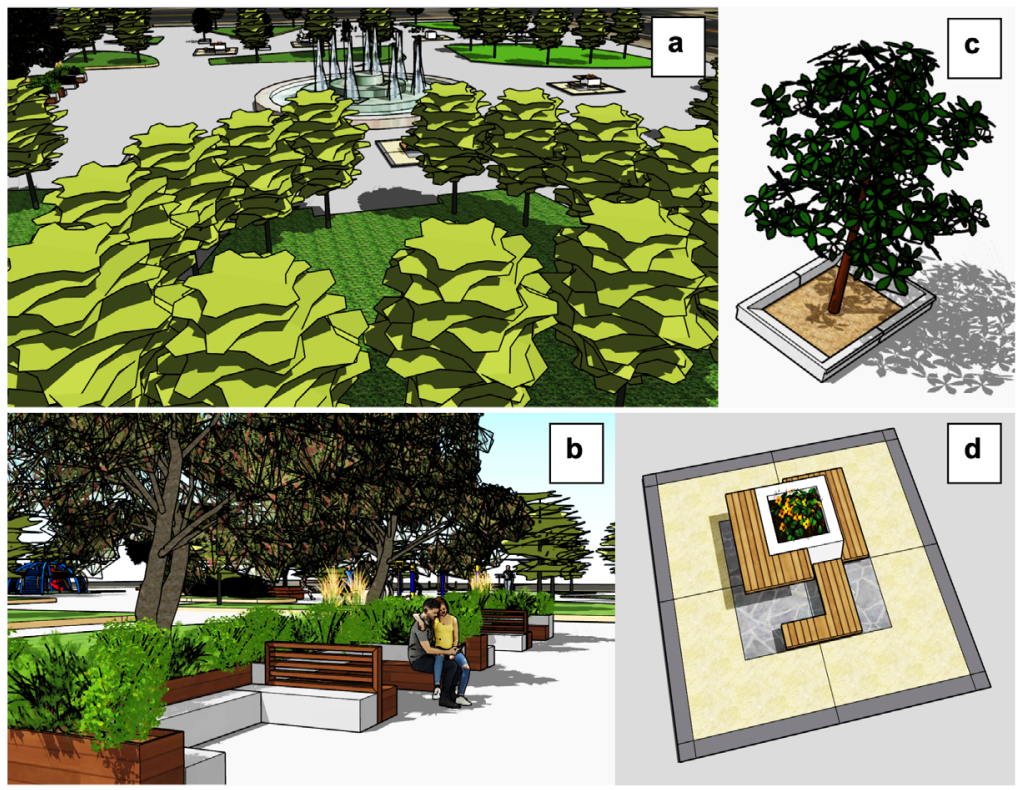

Figure 4. Design proposal for eco-friendly spaces. View towards the main pool with a predominance of abundant trees (a). Schinus terebinthifolius or coastal molles are easily adaptable to the capital's desert climate due to their minimal water consumption (b). Location in some areas of tree pits or bowls to store irrigation or rainwater (c). Solid Meet \& Work system combinations of benches, tables, and planters offer an innovative alternative (d). Source: own elaboration.
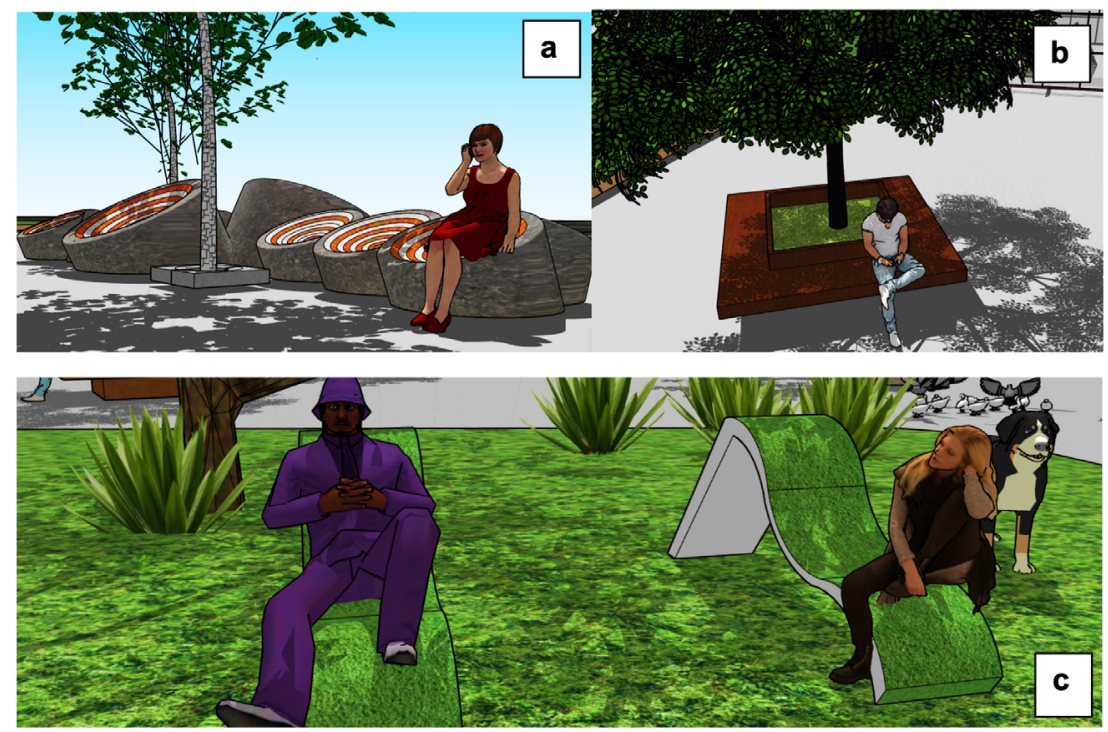

Figure 5. Innovative urban furniture responds to and adapts to the design in the study area (a) and (c). Concrete Tree Planters located in the park sectors (b).

Source: own elaboration. 


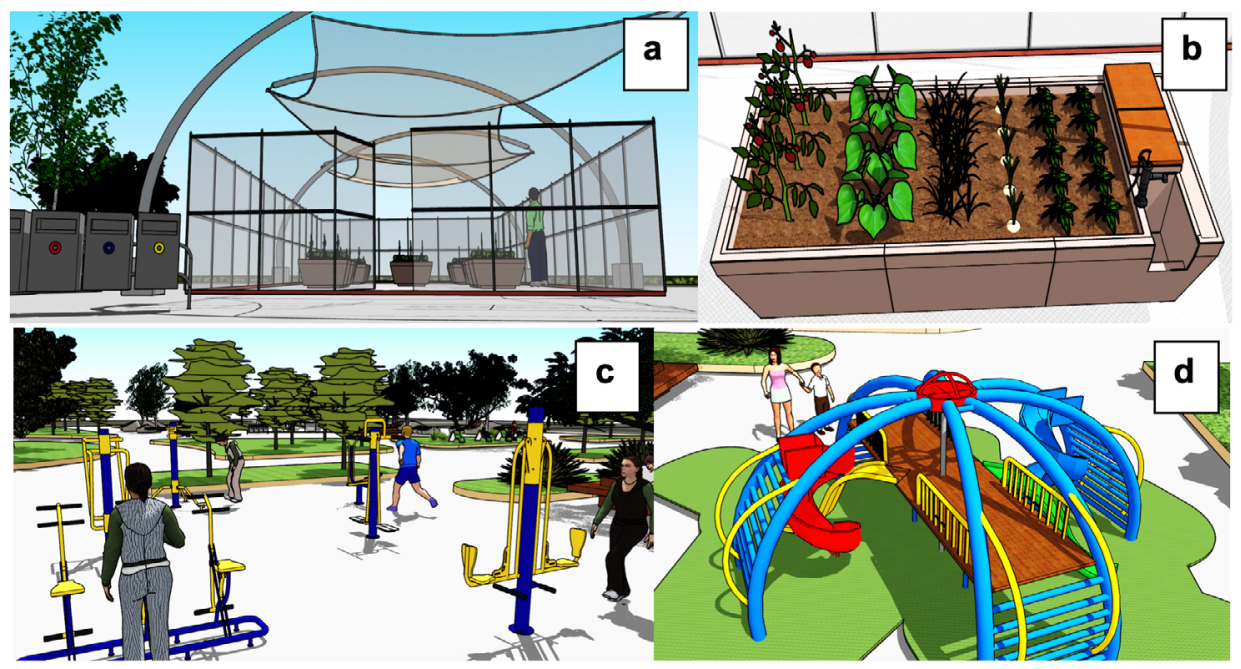

Figure 6. Design proposal for children's recreational spaces. Front view of the urban garden (a). Cultivation of vegetables, vegetables, fruits, legumes, aromatic plants, or medicinal herbs, among other varieties, on a domestic scale (b). Sports area dedicated to benefits for the practice of regular, stable, and moderate physical activity (c). Playground for children (d).

Source: own elaboration.

For the choice of trees in Table 2, the type of soil presented by the Panamericana Sur Sector in San Juan de Miraflores was taken into account. It is a superficial layer of granular soils formed by coarse particles such as sand or gravel, fine and clayey.

Based on the virtual tree guide of Metropolitan Lima, in Figures 4, 5, and 6, some trees for the type of soil that corresponds to our study area require little water consumption, fast growth, and excellent resistance to soils.

Tabla 2. Trees and features.

\begin{tabular}{|c|c|c|}
\hline Scientific name & Common name & Characteristics \\
\hline $\begin{array}{l}\text { Schinus } \\
\text { terebinthifolius }\end{array}$ & Molles costeños & $\begin{array}{l}\text { Tree } 7 \text { to } 10 \mathrm{~m} \text { tall, with evergreen leaves with widespread } \\
\text { ramifications, with red fruits, adapts very well to all soil types. It } \\
\text { requires little maintenance. }\end{array}$ \\
\hline Schinus molle & Molles Serranos & $\begin{array}{l}\text { A medium-sized tree can measure between } 15 \text { meters in height } \\
\text { and } 30 \mathrm{~cm} \text { in diameter, adapts very well to all types of soils, high } \\
\text { resistance to water scarcity, and low maintenance. }\end{array}$ \\
\hline Tecoma stans & Huaranhuay & $\begin{array}{l}\text { 8-meter tall tree, whose main characteristic is that during the } \\
\text { summer, they fill with numerous yellow flowers, adding great beauty } \\
\text { to the landscape. It prefers sandy soils with good drainage. }\end{array}$ \\
\hline $\begin{array}{c}\text { Koelreuteria } \\
\text { paniculata }\end{array}$ & Papelillos & $\begin{array}{l}\text { A medium tree that reaches between } 10 \text { and } 15 \mathrm{~m} \text { in height adapts } \\
\text { very well to nutrient-poor and sandy soils. It resists prolonged } \\
\text { droughts very well. Resists high contamination. }\end{array}$ \\
\hline
\end{tabular}




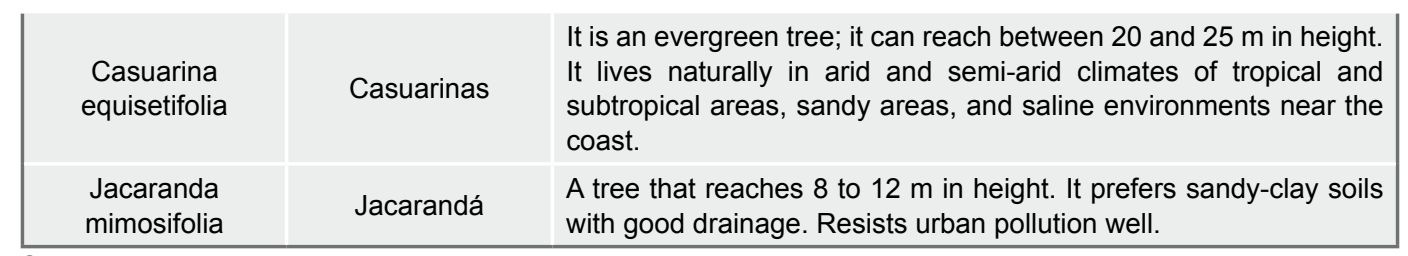

Source: own elaboration.

Table 2 shows the characteristics of the vegetation that have been selected according to their nature and the adaptability of the trees.

\section{CONCLUSIONS}

The proposal for the design of green areas aims to improve the population's living conditions and respond to the urgent need to raise the environmental quality of the San Juan de Miraflores district, Panamericana Sur sector. In this sense, the proposal is considered viable, designed to meet those specific needs based on the area's diagnosis.

This work is a first approximation to the preferences of a public that, in general, seeks through green areas to improve their quality of life, since the availability of green spaces in the study area is below that recommended by The OMS.

This proposal for the design of green areas prioritizes spaces within the urban infrastructure that allow us to advance with a vision for the future and the central axis of the San Juan de Miraflores district's sustainability in the Panamericana Sur sector.

The limitations of this study provide the opportunity to carry out new mapping of unprofitable public properties belonging to the State, as well as to recover degraded areas converted into informal garbage dumps, to make way for green places in the different sectors of San Juan de Miraflores, which will allow significantly increase the size of public green space per inhabitant. It is necessary to find and give space to green places that help the sustainability of the district and therefore improve the quality of life.

\section{REFERENCES}

Berrocal, S. D. (2020). Resiliencia urbana, crecimiento demográfico y cambio climático: la estructura ecológica y las áreas verdes urbanas vinculadas al río Rímac de Lima. South Sustainability, 6 . 
Esenarro, D., Escate, I., Anco, L., Tassara, G., \& Rodriguez, C. (2020). Proposal for an Ecological Research Center for the Recovery and Revaluation of Biodiversity in the Town of Quichas-Lima, Peru. International Fournal of Environmental Science and Development, 11(4), 212-216. http://www.ijesd.org/show-151-1743-1.html

Falcón, A. (2007). Espacios verdes para una ciudad sostenible. Editorial Gustavo Gilli, S.L. https://dialnet.unirioja.es/servlet/libro?codigo $=301825$

Flores-Xolocotzi, R., \& González-Guillen, M.deJ. (2010). Planificación de sistemas de áreas verdes y parques públicos. Revista mexicana de ciencias forestales, 1(1), 17-24. http:/ / www.scielo.org. mx/scielo.php?pid=S2007-11322010000100003\&script=sci_ abstract\&tlng=es

Gómez, N. J., \& Velázquez, G. A. (2018). Asociación entre los espacios verdes públicos y la calidad de vida en el municipio de Santa Fe, Argentina. Cuadernos de Geografia: Revista Colombiana de Geografia, 21(1), 167-179. https://dialnet.unirioja.es/servlet/ articulo? codigo $=6301665$

INEI. (2017). Provincia de Lima Compendio Estadístico. Lima.

Méndez, R., Esenarro, D., Amaya, P., \& Rodriguez, G. (2020). Vulnerability of the soils of Metropolitan Lima and their relationship with urban sustainability. $3 C$ Tecnología. Glosas de innovación aplicadas a la pyme. Edición Especial, Octubre 2020, 161-177. https://ojs.3ciencias.com/index.php/3c-tecnologia/article/view/1101

Miyasako, E. G. (2009). Las áreas verdes en el contexto urbano de la ciudad de México. Universidad de Alicante (España). https:// dialnet.unirioja.es / servlet/tesis?codigo=66881

Morales, V., Piedra, L., Romero, M., \& Bermúdez, T. (2018). Indicadores ambientales de áreas verdes urbanas para la gestión en dos ciudades de Costa Rica. Revista Biología Tropical, 66(4), 1421-1435. https://medes.com/publication/138861

Moyano, E., \& Priego, G. (2009). Marco teórico para analizar las relaciones entre paisaje natural, salud y calidad de vida. Sociedad Hoy, 16, 31-44. https://digital.csic.es/ bitstream/10261/63540/1/Marco\%20Te\%C3\%B3rico\%20para\%20analizar\%20 
las $\% 20$ relaciones $\% 20$ entre $\% 20$ paisaje $\% 20$ natural $\% 2 \mathrm{C} \% 20$ salud $\% 20 y \% 20$ calidad $\% 20 \mathrm{de}^{0} \% 20$ vida.pdf

Municipalidad distrital de San Juan de Miraflores. (2012). Plan de desarrollo concertado 2012-2021 distrito de San Fuan de Miraflores. Ordenanza Municipal No 241-2012. http://imp.gob.pe/wp-content/uploads/2020/09/san_juan_de_miraflores_plan_ de_desarrollo_concertado_2012_2021.pdf

Amaya, P., Esenarro, D., Rodriguez, C., Vega, V., \& López, J. (2020). Economic valuation of environmental attributes of the Yanachaga-Chemillén National Park via contingent valuation and choice experiment. World fournal of Engineering. https:/ / doi.org/10.1108/WJE-09-2020-0407

Ramos, L., Esenarro, D., Rodriguez, C., \& Lagos, J. (2020). Recovery of public spaces for the conservation of green areas in Tablada Lurin. In IOP Conference Series: Materials Science and Engineering, 910, 012020. https://doi.org/10.1088/1757899X/910/1/012020

Reyes, S., \& Figueroa, I. M. (2010). Distribución, superficie y accesibilidad de las áreas verdes en Santiago de Chile. EURE, 36(109), 89-110. http://dx.doi.org/10.4067/ S0250-71612010000300004

Salvador, P. (2003). La planificación verde en las ciudades. Editorial Gustavo Gilli, S. L. https:// dialnet.unirioja.es/servlet/libro? codigo $=171424$

Segovia, E. L., Esenarro, D., Ascama, L., Rodriguez, G., \& Julca, M. S. Y. R. (2020). Design of Green Infrastructure for Sustainable Urban Transportation in Lomas Del Paraiso in Villa Maria Del Triunfo. Journal of Green Engineering (fGE), 10(11), 11180 11192. https://siis.unmsm.edu.pe/es/publications/design-of-green-infrastructurefor-sustainable-urban-transportati

SINIA. (2016). Anuario de Estadisticas Ambientales 2016. Lima. https:/ / sinia.minam.gob.pe/ documentos/anuario-estadisticas-ambientales-2016

Vega, V., Esenarro, D., Maldonado, G., Rodriguez, G., \& Córdova, A. (2020). Green infrastructure design for connectivity in the villa wetlands wildlife refuge. 
Journal of Green Engineering (fGE), 10(12), 2753-12765. https://siis.unmsm.edu.pe/ es/publications/green-infrastructure-design-for-connectivity-in-the-villa-wetland 